\title{
CLIL Approaches in Education: Opportunities, Challenges, or Threats?
}

\author{
Enfoques de AICLE en la educación: ¿oportunidades, \\ desafíos o amenazas?
}

Abordagens de AICL/CLIL na educação: oportunidades,
desafios ou riscos?

Jermaine S. MCDOUGALD*

\section{INTRODUCTION}

Education has always brought about challenges in society for as long as we can remember. However, when variables such as bilingualism or even focusing on content and language integration are added, what comes next is no mystery. Many educators, regardless of their field, have come across many different hurdles in the classroom, from preschool to higher education. Nevertheless, they have always seemed to overcome these challenges through research, training, policy, creativity and plain old innovation. This does not come as a surprise, since the success of any nation is related to how educated their citizens are. Nations invests enormous amounts of their GDP (1.6\% to 12.8\%, according to the World Bank, 2016) on education and new policy in language development and even more on research. There is no set price on education; however, it would be much costlier to a nation if they did not invest in education, since it is a fundamental right that everyone has and it is of vital importance for the future of any country (Global Economic Symposium, 2012).

* Universidad de La Sabana, Colombia.jermaine.mcdougald@unisabana.edu.co

To reference this article / Para citar este artículo / Para citar este artigo

McDougald, J.S. (2016). CLIL Approaches in Education: Opportunities, Challenges, or Threats?, Latin American Journal of Content and Language Integrated Learning, 9(2), 253-266. doi:10.5294/laclil.2016.9.2.1 
Our world is constantly changing; hence, the importance of being able to respond to its demands is of utmost importance. There is an enormous need to innovate and create, as well as apply new and/or different ways of doing things in every aspect of life, including education, which has evolved over the years and will continue doing so for years to come. This is why different approaches to learning have appeared (Coyle, 1999, 2009; Deyrich \& Kari Stunnel, 2014a), amongst them CLIL (content and language integrated learning), an approach which in its original conception was about teaching and learning not only language but also content. Nowadays people "need to learn a language to confront the demands of a new society; the studied language may provide a better status and the possibility to use it for different needs" (Rodriguez Bonces, 2012, p. 180). And what better way could there be to learn it than through a meaningful, real, and contextualized approach such as CLIL? As Rodriguez Bonces (2012) suggests, CLIL increases motivation since "language is used to fulfill real purposes, its use is authentic and much more meaningful for the students" (p. 183). This argument alone has provided many institutions with a viable option to look for something different in the classroom.

In addition, when a second or foreign language is involved, the recipe for education gets a bit more complicated, especially when the same desired results are expected, using the same approaches and methodologies as before. CLIL is no stranger to all of this, in that it brings together both content and language in hopes of providing educators with a real-time response that is context driven, so that education in a second or foreign language can be successful.

\section{CLIL PRINCIPLES}

There are several ways CLIL could be defined; however, Temirova and Westall (2015) remind us that CLIL is "a pedagogical approach in which language and subject area content are learnt in combination. The generic term CLIL describes any learning activity where language is used as a tool to develop new learning from a subject area or theme" (p. 217). Or even a "dual focused objective would seem to be implying that CLIL kills two birds with one stone" Ball, (2002, p. 2). 
When institutions decide on implementing CLIL, there are several aspects that need to be taken into account, among them motivation, which plays a crucial part in this process. Darn (1996) posits that "natural use of language can boost a learner's motivation towards learning languages [....] Language is learnt more successfully when the learner has the opportunity to gain subject knowledge at the same time" (p. 4). However, it is very clear that the $4 \mathrm{Cs}$, as discussed by Coyle, Hood and Marsh (2010), where there is once again a combination of content, cognition, communication, and culture (the $4 \mathrm{Cs}$ framework), thereby allowing students to not only experience significant learning but to gain a wider vision of the world in which they live. Therefore, it is no surprise that using an approach such as this can bring about many positive changes in the classroom-yet the changes do not come easy in terms of implementation.

\section{CHALLENGES IN IMPLEMENTATION}

Implementation, regardless of the context and/or environment, does not come easy, and aside from the obvious factors such as time tables, qualified teachers, budget, resources, there are other issues that also need to be dealt with that are often left out. This editorial focuses on 4 key issues that are seldom taken into consideration or even a topic of conversation among practitioners: (1) opposition to language teaching by subject teachers, (2) experimental CLIL programs, (3) SLA skills needed by subject content teachers, and (4) lack of CLIL teacher-training programs.

Opposition to language teaching by subject teachers may come from language teachers themselves. Indeed, English teachers themselves are often the ones that put up a fight regarding non-language teaching professionals "invading" their language-teaching territory. This is an area in which both sides, language teachers and content teachers, clearly do not always see eye-to-eye, mainly because there is a lack of opportunities to collaborate in the curriculum. Woźniak (2013, p. 2) claims both types of teachers that are involved require further training on collaboration in order to know how this process should be developed and improved to support and maintain an effective integration of both content and language. McDougald (2009) also argues that content specialists should be given 
more opportunities in connection with language learning and teaching in order to successfully promote students' language skills.

Teachers are much too concerned with trying to deliver individual, isolated "results", without considering the whole or the overall learning process. If teachers were to lower their guard, and be much more open to new opportunities-including collaboration and team work-they all would be able to work towards a "vision of CLIL" in which institutional goals supersede individualized goals that both content and language teachers often strive to obtain. Ruiz Garrido and Gómez (2009) also remind us that all teacher training and collaboration activities within a given institution should be part of a global institutional strategy with clear objectives and recognition of the effort made by the parties involved. Cenoz (2013) and Genoz, Genesee, and Gorter (2013) have also insisted that institutional goals are needed so that success across the board can be accomplished.

\section{EXPERIMENTAL CLIL PROGRAMS}

It is clear that a CLIL approach is very much "context driven", in that there are a variety of ways for it to be delivered within the same institution. CLIL programs have been emerging throughout Colombia and Latin America in recent years. Partly due to the CLIL trend in Latin America, institutions have been looking for new ways of managing bilingual programs, however claiming a "CLIL" approach as their own, without any real connection to this approach. CLIL implementations have been reported in approximately 175 officially registered bilingual schools in Colombia in which more than $50 \%$ of the subjects at the primary or secondary level are taught through English or through Spanish, French, Italian, or German (McDougald, 2015; Rodríguez, 2011). However, although many of these educational institutions claim to have some kind of a CLIL program, when asked about why they have chosen CLIL, or what is CLIL, or even about certain characteristics of their program, one often receives answers that lead to the conclusion that these are merely generic bilingual programs, offering English language instruction within the curriculum, that are using the term CLIL as a catch-all phrase because CLIL has become a buzzword in the language-teaching community. 
Science is all about experimenting, looking for new ways of doing things, coming up with new results - or even different results for that matter. However, when the experimentation has concluded, there should be some type of documentation of the "lessons learned" so that others can pick up and have more success. Unfortunately, there has been little research on CLIL implementation in Latin America covering all aspects of implementation. However, there have been dozens of isolated CLIL endeavors focusing on issues such as teacher training (Deyrich \& Kari Stunnel, 2014b; Hillyard, 2011; Marsh, Mehisto, Wolff, \& Frigols-Martín, 2011) or perceptions and material design (Arnold, 2010; Dario Luis Banegas, 2012; Darío Luis Banegas, 2016; Mehisto, 2012; Meyer, 2010). In a recent study conducted by Arribas (2016), the attitudes, motivation, and receptive vocabulary of two groups of students, one in a regular English class and the other in a CLIL class were evaluated. As has also been found in other studies, the students in the CLIL group scored higher in receptive vocabulary, apparently due to motivation; nevertheless, it was also found that CLIL was perceived as being of "little" or "very little help" (p.15). Arribas concluded that the negative attitude towards CLIL may have to do with the fact that the implementation thus far was "somewhat irregular in the school" (p. 21) and this may have had a negative effect on the students' attitude.

\section{LACK OF CLIL TEACHER-TRAINING PROGRAMS}

What is being done to make and mold the ideal CLIL teacher that actually has the know-how needed to make CLIL programs successful? It is safe to say that teachers currently teaching in schools have already undertaken studies at the school and university levels at which the foreign language(s) to which they were exposed or that they acquired did not receive the necessary attention needed in order to properly acquire that language. In many cases, these teachers were well versed in grammar aspects and may even have had to sacrifice their oral skills to comply with the different methodologies then in use. Coonan (2011) claims that such situations result in "a large-scale teacher population without the language qualifications required for quality CLIL teaching" (p.4). Nevertheless, such learned behavior is often recycled and repeated by these teachers in their own, current day- 
to-day teaching practices-so where does CLIL come in? How are educators, universities, policy makers, and stakeholders going to bridge the gap so that pre- and in-service teachers can change their practices in preparation for the CLIL era? This is one reason that working together, in teams, and collaborating with one another has been common a response to overcoming the particular obstacle of lack of proper teacher-training programs (Conn, 2010; Leavitt, 2006).

Yet, on another note, teacher-training programs attempting to cater to the needs of CLIL approaches are often insufficient (Hillyard, 2011; Lasagabaster \& Ruiz de Zarobe, 2010; Pistorio, 2009) due to quantity and complexity of the variables that affect CLIL programs. For example, amongst the variable that need to be considered when planning a teacher-training program are context, evaluation of both language and content, type of educational institutional (preschool, primary, secondary or even higher education), hours, model or type of program, language used, metacognitive strategies, or even the teacher's prior experience (Dario Luis Banegas, 2012; Dalton-Puffer, 2011; Hillyard, 2011; McDougald, 2009). Moreover, Arnó-Macià and Mancho-Barés (2015) discuss the need to train "content lecturers" to develop graduates' proficiency in English, once again increasing communicative competences needs. Considering that CLIL is not easy to put into practice, it is key that "a strong collaboration among subject teachers and language teachers"(Biçaku, 2011, p. 4); this is partially because these types of classes can be most effective when there is a large range of activities. By working together, training both content and language teachers to collaborate in developing and implementing the most appropriate kinds of tasks for their learners, CLIL outcomes could be much more successful.

\section{IN THIS ISSUE}

This issue of the Latin American Journal of Content and Language Integrated Learning includes papers that highlight a number of different possibilities about what can be done with CLIL implementation in countries such as Colombia, Spain, Iran and Italy. Arribas (2016) starts the issue in Spain by exploring students' attitudes, motivation, and receptive vocabulary, using two control groups to examine whether CLIL really makes a 
difference in terms of vocabulary acquisition. The results encourage reflection on what learners actually want and need in order for learning to take place. Motivation is a key ingredient in any learning process, not just in CLIL environments.

Along the same lines, Corrales, Pabab Rey, Lourdes, and Escamilla (2016) conducted a case study on perceptions amongst students, teachers and administrators about using English as a medium of instruction (EMI) at a private university in Colombia. Questions were raised as to why EMI was being introduced at this particular university, and the authors suggested that implementation of EMI could benefit by adding elements of the CLIL approach to support learning, since students reported having problems understanding the taught concepts in English. Furthermore, CLIL could help them-both teachers and students-establish connections between international and intercultural competences, all the while providing teachers with a purpose for using content and language in the classroom.

Evaluation and assessment are areas that institutions often ignore when trying to implement a CLIL model. Continuous evaluation and assessment in a CLIL class is a must and fundamental for observing progress in both content and language. Leal (2016) focused her study on test development with a CLIL focus, in which she used several control groups to determine the effectiveness of both content and language learning in a natural sciences class in a primary school in Colombia. Through a systematic examination of test items, in which formal item analysis was used to depict test validity, Leal found that the assessment grid used in the study, which integrated key elements such as content, knowledge levels, CALP functions and cognitive skills, was an essential aid to measuring the state of the learning process, especially with regards to the foreign language. The assessment grid helped practitioners discriminate language and content achievement, while also aiding the subject teacher in understanding language demands as well as levels of difficulty of content-oriented tasks. Such a grid could prove useful for school administrators and decision makers by helping guide and evaluate the implementation process within different subject areas.

Along with assessment, foreign languages standards are also critical when looking at an institution as a whole, especially when dealing 
with the implementation of programs and/or educational models. Castillo and Pineda-Puerta (2016) introduce the term illusio in regard to foreign language standards, in which many believe that foreign language policies/standards exist when in fact they may not. This concept has seldom been explored at public institutions in Colombia, leaving a certain degree of doubt about the extent to which any such language policies may be a reality. The preliminary results from this small-scale study suggests that well-intended national policy goals have not been realized because some institutions invest neither in their staff (teachers, administrators) nor in the resources necessary to meet the demands, requirements, and objectives established by the Colombian Ministry of Education's Bilingual Program successfully. Nevertheless, the article provides good evidence that, with continued program evaluation and needs analysis, both critical elements, institutions could improve the quality of policy implementations and be able to make more informed program decisions.

Materials development has always been at the forefront of conversations on CLIL, especially with regards to the use of authentic and/or genuine materials in the CLIL classroom. We all agree that CLIL is context orientated, making it impossible at times to find the "right material" for a lesson, let alone materials that also provide culturally enriching elements to further promote the teaching and learning process. Zhyrun's (2016) pilot study focused on an innovative approach to adapting YouTube materials so as to include contextualized cultural elements, in which language is adjusted, thereby making it easier for students to understand the language used in the videos. The newly adapted videos included information related to students' lives, on which positive emotions and feelings were expressed. This pilot study used CLIL videos to help bridge the gap between the concepts studied, including the local culture, making learning much more meaningful and enjoyable for students, thereby increasing the opportunities for learning to take place.

Ghaedrahmat, Alavi Nia, and Biria (2016) present a pragmatic study on speech acts-more specifically, the speech act of "thanking" - to examine the extent to which EFL learners could improve their pragmatic awareness. Pragmatic transfer takes place when there is a difference in how a language is used as a result of L1 norms and culture, which in turn affect 
the way the L2 is used. In this study, the differences between Persian (L1) and English (L2) were quite important, since different cultural norms associated with the two languages make a difference in expressing the language effectively; just because learners may be linguistically competent, this does not guarantee that they will be pragmatically competent. Studies as this one lead to further discussion about how culture can play an important role in assimilating content within a CLIL approach. This paper contributes to debate in which scholars such as Dalton-Puffer (2006, 2007, 2011)and Maillat (2010) have also looked closely at how discourse analysis and pragmatics relate to CLIL, so that the teaching and learning processes can be more meaningful for learners.

This issue also includes a general look at the long process of bringing CLIL into the mainstream of education in Italy, as Cinganotto (2016) describes some of the most important steps in this process, along with relevant implications for policymakers, teachers, and students elsewhere. Italy's steps towards implementing CLIL in mainstream education, which date back to the 1990s, provided clear examples of how policies have been put into place, as well as the innovation and creativity needed in terms of implementation. Of particular note is the planning of teacher-training programs aimed at fulfilling a purpose-designed CLIL teacher profile that makes it clear to all those involved what skills teachers are expected to have. Cinganotto also considers in greater depth the process of CLIL implementation in an upper secondary school setting, discussing insights, best practices and opportunities relevant to future CLIL endeavors.

\section{CONCLUSION}

In conclusion, there are many factors to be considered and, indeed, explored when considering how to implement CLIL-whether partially, fully, or even not at all. Even the numerous issues addressed by the authors of the articles in the present issue of the Latin American Journal of Content and Language Integrated Learning represent only a mere fraction of what is actually going on throughout Latin America, Europe, and elsewhere. CLIL stakeholders have an obligation to the educational community to learn from what has been done, clearly map out the reasons for why 
CLIL would be an option in a particular instance, and to set up provisions for short, medium, and long-term teacher training. The "CLIL teacher profile" is quite different than what we are perhaps accustomed to, requiring more collaboration, teamwork, and comprehension. This editorial can, of course, by no means offer a simple solution to CLIL implementation, but it does extend an invitation to expand the debate in terms of experimental CLIL programs, the skills needed by subject content teachers, and how to address the lack of CLIL teacher-training programs.

\section{REFERENCES}

Arnó-Macià, E., \& Mancho-Barés, G. (2015). The role of content and language in content and language integrated learning (CLIL) at university: Challenges and implications for ESP. English for Specific Purposes, 37, 63-73. http://dx.doi.org/10.1016/j.esp.2014.06.007

Arnold, W. (2010). Where is CLIL taking us? Pulso, 33, 227-233. Retrieved from http://dspace.uah.es/jspui/bitstream/10017/7214/1/Where Arnold_PULSO_2010.pdf

Arribas, M. (2016). Analysing a whole CLIL school: Students' attitudes, motivation, and receptive vocabulary outcomes. Latin American Journal of Content and Language Integrated Learning, 9(2), 267292. http://dx.doi.org/10.5294/laclil.2016.9.2.6

Ball, P. (2002). Article: What is CLIL? | Onestopenglish. , (Clil), 11-13. Retrieved from http://www.onestopenglish.com/clil/methodology/ articles/article-what-is-clil/500453.article

Banegas, D. L. (2012). CLIL teacher development: Challenges and experiences. Latin American Journal of Content and Language Integrated Learning, 5(1), 46-56. http://dx.doi.org/10.5294/laclil.2012.5.1.4

Banegas, D. L. (2016). Teachers develop CLIL materials in Argentina: A workshop experience. Latin American Journal of Content and Language Integrated Learning, 9(1), 17-36. http://dx.doi.org/ doi:10.5294/laclil.2016.9.1.2 
Biçaku, R. C.. (2011). CLIL and teacher training. Paper presented at the Procedia - Social and Behavioral Sciences. http://dx.doi.org/10.1016/j. sbspro.2011.04.379

Castillo, R. \& Pineda-Puerta, A. (2016). The illusio of the foreign language standard in a Colombian university. Latin American Journal of Content \& Language Integrated Learning, 9(2), 426-450. http:// dx.doi.org/10.5294/laclil.2016.9.2.8

Cenoz, J. (2013). Discussion: Towards an educational perspective in CLIL language policy and pedagogical practice. International Journal of Bilingual Education and Bilingualism, 16(3), 389-394. http:// dx.doi.org/10.1080/13670050.2013.777392

Cenoz, J., Genesee, F. \& Gorter, D. (2013). Critical analysis of CLIL: Taking stock and looking forward. Applied Linguistics, 35(3), 243-262. http:// dx.doi.org/10.1093/applin/amto11

Cinganotto, L. (2016). CLIL in Italy: A general overview. Latin American Journal of Content \& Language Integrated Learning, 9(2), 374-400. http://dx.doi.org/10.5294/laclil.2016.9.2.6

Conn, C. E. (2010). Learning the hard way (but still learning!): Using team teaching as a vehicle for pedagogical change.Business Communication Quarterly, 73, 87-91. http://dx.doi.org/10.1177/1080569909358098

Coonan, C. M. (2011). CLIL in (language ) teacher training. Studi Di Glottodidattica, 2(1), 1-14.

Corrales, K. A., Paba Rey, Lourdes, A. \& Escamilla, N. S. (2016). Is EMI enough? Perceptions from university professors and students. Latin American Journal of Content \& Language Integrated Learning, 9(2), 318-344. http://dx.doi.org/doi:10.5294/laclil.2016.9.2.4

Coyle, D. (1999). Supporting students in content and language integrated learning contexts: Planning for effective classrooms. In J. Masih (Ed.), Learning through a foreign language: Models, methods and outcomes (pp. 46-62). London, England: CILT Publications. Retrieved from http://www.eric.ed.gov/PDFS/ED454735.pdf 
Coyle, D. (2009). Transforming classrooms: Opportunities and issues for CLIL. .

Coyle, D., Hood, P. \& Marsh, D. (2010). CLIL: Content and language integrated learning. Cambridge, UK: Cambridge University Press.

Dalton-Puffer, C. (2006). Pragmatics of content-based instruction: Teacher and student directives in Finnish and Austrian classrooms. Applied Linguistics, 27(2), 241-267.http://dx.doi.org/10.1093/applin/amloo7

Dalton-Puffer, C. (2007). Discourse in content and language integrated learning (CLIL) classrooms. Amsterdam, the Netherlands: Benjamins. Retrieved from https://www.academia.edu/4692561/ Discourse_in_Content_and_Language_Integrated_Learning_ CLIL_classrooms

Dalton-Puffer, C. (2011). Content-and-language integrated learning: From practice to principles? Annual Review of Applied Linguistics, 31,182204. http://dx.doi.org/10.1017/So267190511000092

Darn, S. (1996). Content and Language Integrated Learning ( CLIL ) A European Overview. Internationa Journal of English Studies, 12(1), 79-96. http://dx.doi.org/10.1080/14790718.2012.665454

Deyrich, M.-C. \& Kari Stunnel. (2014a). Language education models: New issues and challenges. In English as a foreign language teacher education: Current perspectives and challenges (p. 364).

Deyrich, M.-C., \& Kari Stunnel. (2014b). Language education models: New issues and challenges. In J. de D. Martínez Agudo (Ed.), English as a foreign language teacher education: Current perspectives and challenges (pp. 83-106). Leiden, the Netherlands: Brill.

Ghaedrahmat, M., Alavi Nia, P. \& Biria, R. (2016). The effect of explicit Vs. implicit instruction on mastering the speech act of thanking among Iranian male and female EFL learners. Latin American Journal of Content \& Language Integrated Learning, 9(2), 401-425. http://dx.doi.org/10.5294/laclil.2016.9.2.7

Global Economic Symposium. (2012). Effective investments in education. Knowledge Base. Retrieved from http://www.global-economicsymposium.org/knowledgebase/the-global-economy/effectiveinvestments-in-education 
Hillyard, S. (2011). First steps in CLIL: Training the teachers. Latin American Journal of Content and Language Integrated Learning , 4(2), 1-12. http://dx.doi.org/10.5294/laclil.2011.4.2.1

Lasagabaster, D. \& Ruiz de Zarobe, Y.(Eds.) (2010). CLIL in Spain:Implementation, results and teacher training. Newcastle upon Tyne, UK: Cambridge Scholars Publishing.

Leal, J. (2016). Assessment in CLIL: Test Development at Content and Language for Teaching Natural Science in English as a Foreign Language.Latin American Journal of Content \& Language Integrated Learning, 9(2), 293-317. http://dx.doi.org/10.5294/laclil.2016.9.2.3

Leavitt, M. (2006). Team-teaching: The benefits and challenges. Speaking of Teaching, 16(1), 1-4.

Maillat, D. (2010). The pragmatics of L2 in CLIL. In Language Use and Language Learning in CLIL Classrooms (pp. 39-58). http://dx.doi. org/10.1075/aals.7.03mai

Marsh, D., Mehisto, P., Wolff, D., \& Frigols-Martín, M. J. (2011). European framework for CLIL teacher education. Graz, Austria: European Centre for Modern Languages. Retrieved from http://www.ecml. at/tabid/277/PublicationID/62/Default.aspx

McDougald, J. S. (2009). The state of language and content instruction in Colombia. Latin American Journal of Content and Language Integrated Learning, 2(2), 44-48. http://dx.doi.org/10.5294/ laclil.2009.2.2.15

McDougald, J. S. (2015). AICLE: un nuevo enfoque para el aprendizaje bilingüe/CLIL: A fresh approach to bilingual learning. Ruta Maestra, 11, 30-38. Retrieved from http://www.santillana.com. co/rutamaestra/edicion-11/articles/5

Mehisto, P. (2012). Criteria for producing CLIL learning material. Encuentro, 21, 15-33. Retrieved from http://files.eric.ed.gov/fulltext/ED539729.pdf Meyer, O. (2010). Towards quality CLIL: Successful planning and teaching strategies. Pulso, 33, 11-29. Retrieved from http://dspace.uah. es/dspace/bitstream/handle/10017/7204/Towards_Meyer_ PULSO_2010.pdf

Pistorio, M. I. (2009). Teacher training and competences for effective CLIL teaching in Argentina. Latin American Journal of Content and 
Language Integrated Learning, 2(2), 37-43. Retrieved from http:// journals.sfu.ca/laclil/index.php/LACLIL/article/view/18/12

Rodríguez, M. (2011). CLILL: Colombia leading into content language learning. Íkala, 16(28), 79-89.

Rodriguez Bonces, J. (2012a). Content and language integrated learning (CLIL): Considerations in the Colombian context. GIST: Education and Learning Research Journal, 6(6), 177-189.

Ruiz-Garrido, M. \& Gómez, I. F. (2009). Needs analysis in a CLIL context: A transfer from ESP. In D. Marsh, P. Mehisto, D. Wolff, R. Aliaga, T. Asikainen, M. J. Frigols-Martin, ... G. Langé (Eds.), CLIL Practice: Perspectives from the field (pp. 179-188). Jyväskylä, Finland: CLIL Cascade Network, University of Jyväskylä. Retrieved from http:// scholar.google.com/ scholar?hl=en\&btnG=Search\&q=intitle: Needs+Analysis+in+a+CLIL+Context+:+A +Transfer+from+ESP\#o Temirova, F. \& Westall, D. (2015). Analysis of first and foreign language use in content and language integrated learning (CLIL) classrooms. Procedia - Social and Behavioral Sciences, 178, 217-221.http://dx.doi. org/10.1016/j.sbspro.2015.03.184

World Bank. (2016). Government expenditure on education, total (\% of GDP) (SE.XPD.TOTL.GD.ZS). World Development Indicators. Retrieved from http://databank.worldbank.org/data/reports.aspx? source= 2\&series=SE.XPD.TOTL.GD.ZS\&country

Woźniak, M. (2013). CLIL in Pharmacy: A case of collaboration between content and language lecturers. Language Value,5(1).http://dx.doi. org/10.6035/LanguageV.2013.5.6

Zhyrun, I. (2016). Culture through comparison: Creating audio-visual listening materials for a CLIL course. Latin American Journal of Content \& Language Integrated Learning, 9(2), 345-373. http:// dx.doi.org/10.5294/laclil.2016.9.2.5 